\title{
Alteration of the Respiratory Burst and Phagocytosis of Macrophages under Protein Malnutrition
}

\author{
Shigetada Teshima, Kazuhito RoKutan, ${ }^{*}$ Masayuki TAKAHAshi, ${ }^{1}$ \\ Takeshi NikAwA, Yasuhiro KIDO, and Kyoichi KISHI \\ Department of Nutrition, School of Medicine, The University of \\ Tokushima, Tokushima 770, Japan \\ ${ }^{1}$ Cellular Technology Institute, Otsuka Pharmaceutical Co., Ltd., \\ Tokushima 771-01, Japan
}

(Received August 25, 1994)

Summary To understand the role of macrophages in impaired host defense under protein malnutrition (PM), we examined the activities of the respiratory burst and phagocytosis of resident peritoneal macrophages from weaning female mice fed $5 \%$ casein or $5 \%$ soy protein isolate (SPI) diet for 14 days. Resident macrophages from the low-protein diet groups released larger amounts of superoxide anion $\left(\mathrm{O}_{2}^{-}\right)$after stimulation by phorbol 12-myristate 13-acetate (PMA) or opsonized zymosan than those from the 20\% casein and 20\% SPI diet groups. Activation of macrophages from protein-deficient mice in vitro with lipopolysaccharide (LPS) or macrophage colony-stimulating factor (M-CSF) under LPS-free conditions did not further enhance $\mathrm{O}_{2}^{-}$production. In spite of the increased $\mathrm{O}_{2}{ }^{-}$production with opsonized zymosan, macrophages from proteindeficient mice did not show any acceleration of phagocytosis of Candida albicans in the presence of normal serum. Our results confirm that the phagocytic function of macrophages is susceptible to PM, and suggest that functional alterations of macrophages may be involved in the failure of development of a specific immune response under PM. Furthermore, the enhanced production of oxygen intermediates by macrophages may augment tissue damage under PM.

Key Words protein malnutrition, macrophages, respiratory burst, phagocytosis, macrophage activation

Nutrition is one of the most important factors to modulate host defense. Many lines of evidence suggest that protein malnutrition (PM) predisposes to microbial infection, particularly to intracellular pathogens (1). Although the extent of impaired immune response depends on the severity of malnutrition, humoral immunity usually remains intact, while cell-mediated immunity is impaired under

* To whom correspondence should be addressed. 
PM (1).

Macrophages play a central role in defense against microbial infection by presenting antigen to lymphocytes during the development of specific immunity and by serving as accessory cells to lymphocytes. They release more than 100 soluble factors, most of which are involved in the regulation of immune response (2). Macrophages also carry out the fundamental protective functions in ingesting and killing invading organisms. During phagocytosis or exposure to certain inflammatory mediators, they release large amounts of oxygen intermediates, including superoxide anion $\left(\mathrm{O}_{2}{ }^{-}\right)$and hydrogen peroxide, which are important for killing microorganisms (3). The enzyme system responsible for the "respiratory burst" is a membrane-bound NADPH oxidase (reviewed in 4). The importance of the respiratory burst activity for host defense is emphasized by the inherited disorder, chronic granulomatous disease, which is a clinical syndrome of severe and recurrent infections characterized biochemically by the absence of the respiratory burst (5).

Compared with $\mathrm{T}$ and $\mathrm{B}$ cell functions, $\mathrm{PM}$-induced alterations of macrophage functions are not well documented. In this study, we focused on the macrophage functions relating to their microbicidal activity, the ability to produce $\mathrm{O}_{2}{ }^{-}$and phagocytosis, under PM produced by low-protein diet consisting of $5 \%$ casein or $5 \%$ soy protein isolate (SPI).

\section{MATERIALS AND METHODS}

Chemicals and media. Recombinant macrophage colony-stimulating factor (M-CSF) (6) and normal saline were donated by Otsuka Pharmaceutical Co. (Tokushima). Superoxide dismutase (SOD, from horse heart), ferricytochrome $c$, phorbol 12-myristate 13-acetate (PMA), zymosan from Saccharomyces cerevisiae, and lipopolysaccharide (LPS, from Escherichia coli K-235) were obtained from Sigma Chemical Co. (St. Louis, MO). Dulbecco's modified Eagle's medium (DMEM) was from Flow Laboratories (McLean, VA). Hanks' balanced salt solution without phenol red (HBSS) was purchased from Nissui Pharmaceutical Co. (Tokyo). Sabouraud's dextrose agar and broth were purchased from Difco Laboratories (Detroit, MI).

Animals and diets. Female $\mathrm{C} 3 \mathrm{H} / \mathrm{He}$-slc mice were purchased from Shizuoka Laboratory Animal Center (Hamamatsu, Japan). Mice at 4 weeks of age were divided into four groups of 10 animals each and fed ad libitum 5\% casein, 20\% casein, 5\% SPI, or 20\% SPI diet for 14 days. The compositions of the diets are listed in Table 1. All mice were allocated to free access to water. The animals were kept in an air-conditioned room at $23 \pm 1{ }^{\circ} \mathrm{C}$. Body weight and food intake were daily measured at 10:00 A.M. Mice were carefully monitored for signs of distress or infection.

Isolation of resident peritoneal macrophages. Resident peritoneal macrophages were prepared in an LPS-free system as previously described (7). All reagents to which macrophages were exposed in culture were free from detectable LPS by 
Table 1. Composition of normal and low protein isocaloric diets.

\begin{tabular}{|c|c|c|}
\hline Ingredient & $5 \%$ protein diet $(\mathrm{g} / \mathrm{kg})$ & $20 \%$ protein diet $(\mathrm{g} / \mathrm{kg})$ \\
\hline Casein or SPI & 50 & 200 \\
\hline$\alpha$-Starch & 557 & 457 \\
\hline Sucrose & 278 & 228 \\
\hline Cellulose & 20 & 20 \\
\hline Corn oil & 50 & 50 \\
\hline Mineral mix ${ }^{1}$ & 35 & 35 \\
\hline Vitamin $\operatorname{mix}^{2}$ & 10 & 10 \\
\hline
\end{tabular}

${ }^{1}$ AIN-76 mineral mixture ( $\mathrm{g} / \mathrm{kg}$ mixture): calcium phosphate dibasic, 500.0; sodium chloride, 74.0; potassium citrate, 220.0; potassium sulfate, 52.0; magnesium oxide, 24.0; manganous carbonate, 3.5; ferric citrate, 6.0; zinc carbonate, 1.6; cupric carbonate, 0.3 ; potassium iodate, 0.001 ; sodium selenite, 0.001 ; chromium potassium sulfate, 0.55 ; cellulose, 118.3. ${ }^{2}$ Vitamin mixture (per gram mixture): all-trans-retinyl palmitate, $500 \mathrm{IU}$; cholecalciferol, $100 \mathrm{IU}$; $\alpha$-tocopherol, $5 \mathrm{mg}$; menadione, $5.2 \mathrm{mg}$; thiamine, $1.2 \mathrm{mg}$; riboflavin, $4 \mathrm{mg}$; pyridoxine, $0.8 \mathrm{mg}$; cyanocobalamin, $0.005 \mathrm{mg}$; ascorbic acid, $30 \mathrm{mg}$; D-biotin, $0.02 \mathrm{mg}$; folic acid, $0.2 \mathrm{mg}$; calcium pantothenate, 5 $\mathrm{mg}$; $p$-aminobenzoate, $5 \mathrm{mg}$; nicotinic acid, $6 \mathrm{mg}$; inositol, $6 \mathrm{mg}$; choline chloride, 200 mg.

the Limulus amebocyte lysate assay (E-toxate, Sigma). Peritoneal cells were collected by washing peritoneal cavity with ice-cold saline. After washing isolated cells twice with cold saline, they were suspended in DMEM, and $3 \times 10^{5}$ cells were placed in each well of 24-well culture plates (Corning Glass Works, Corning, NY). After incubation for $2 \mathrm{~h}$ at $37^{\circ} \mathrm{C}$ in $5 \% \mathrm{CO}_{2}-95 \%$ air, nonadherent cells were removed by washing vigorously with cold saline.

Macrophages were further cultivated in DMEM with $10 \mathrm{ng} / \mathrm{ml} \mathrm{LPS} \mathrm{or} 1 \mu \mathrm{g} / \mathrm{ml}$ $\mathrm{M}-\mathrm{CSF}$, or without any supplement. After cultivation for $12 \mathrm{~h}$, macrophages were subjected to analysis of $\mathrm{O}_{2}^{-}$release. Differential counts of the adherent cells used for experiments were determined microscopically after Giemsa and nonspecific esterase staining. Resident preparations were $>95 \%$ macrophages (7).

Assay of $\mathrm{O}_{2}^{-}$release. $\mathrm{O}_{2}{ }^{-}$released from macrophages was assayed by measuring the SOD-inhibitable reduction of ferricytochrome $c$ by the method of Johnston (8). PMA $(500 \mathrm{ng} / \mathrm{ml})$ or opsonized zymosan $(1 \mathrm{mg} / \mathrm{ml})$ was used as a stimulant. Zymosan was opsonized with normal human serum by the method of Johnston (8). The amounts of $\mathrm{O}_{2}{ }^{-}$released are expressed as $\mathrm{nmol} / \mathrm{mg}$ protein $/ \mathrm{h}$. Cell protein was determined by the method of Lowry et al. (9) using bovine serum albumin as a standard.

Fungi. Stock culture of Candida albicans (ATCC 18804) was maintained on Sabouraud's dextrose agar at $4{ }^{\circ} \mathrm{C}$. To prepare stationary growth-phase yeast, Candida was inoculated into $20 \mathrm{ml}$ Sabouraud's $2 \%$ dextrose broth and incubated for 3 days at room temperature with continuous rocking. The viability of Candida remained $>98 \%$ as determined by the exclusion of $0.01 \%$ methylene blue. 
Assay of phagocytosis. Phagocytosis of Candida by macrophages was measured according to the method of Maródi et al. (10). Five hundred microliters of peritoneal cell suspension containing $1 \times 10^{6}$ macrophages $/ \mathrm{ml}$ was incubated with an equal volume of a suspension of $2 \times 10^{6}$ Candida $/ \mathrm{ml}$ in polypropylene tubes in the presence or absence of $2.5 \%$ normal human serum at $37^{\circ} \mathrm{C}$ for $1 \mathrm{~h}$ under rotation $(4 \mathrm{rpm})$. The aliquots of the mixture $(100 \mu 1)$ were fixed on each glass slide with $70 \%$ methanol, air dried, and stained with Giemsa solution. The percentage of ingested yeast was determined by counting 100 of all extracellular and intracellular Candida. Candida within detectable phagocytic vacuoles was considered intracellular (10).

Statistical analysis. ANOVA and Scheffe's test were used to determine statistically significant differences. Differences were considered significant if the $p$ value was less than 0.05 .

\section{RESULTS}

Effect of low-protein diet on growth and peritoneal cell number

The growth curves of each diet group are shown in Fig. 1. Mice fed 5\% casein diet showed significantly smaller weight gains than the $20 \%$ casein or $20 \%$ SPI diet group $(p<0.01)$. Although mice fed 5\% SPI diet took larger amounts of food than mice fed $20 \%$ protein diets $(p<0.05)$, there was no weight gain in the $5 \%$ SPI diet group, and the weights on day 14 were significantly lower than those of the $5 \%$

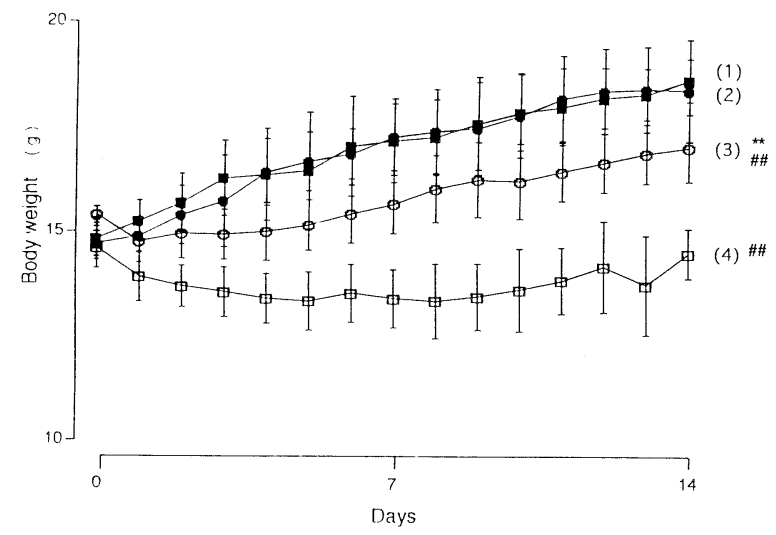
(1) $20 \%$ casein
(2) $20 \% \mathrm{SPI}$
(3) $5 \%$ casein
(4) $5 \% \mathrm{SPI}$

Fig. 1. Growth curve of mice fed different protein diets. Body weights of each diet group were compared on day 14 . Statistical significance was determined by ANOVA and Scheffe's test. Values are mean \pm SD $(=5) . \quad * * p<0.01$ by ANOVA and Scheffe's test (5\% SPI vs. 5\% casein diet group). ${ }^{\#} p<0.01$ by ANOVA and Scheffe's test ( $5 \%$ vs. $20 \%$ casein or SPI diet group). 
Table 2. Effect of low-protein diets on food intake.

\begin{tabular}{cc}
\hline Grops & Food intake $(\mathrm{g} /$ day $)$ \\
\hline $5 \%$ casein & $2.67 \pm 0.59^{*}$ \\
$20 \%$ casein & $2.27 \pm 0.36$ \\
$5 \%$ SPI & $2.78 \pm 0.56^{*}$ \\
$20 \%$ SPI & $2.25 \pm 0.37$
\end{tabular}

Values are mean \pm SE for 6 mice. $*_{p}<0.05$ by ANOVA and Scheffé's test ( $5 \%$ vs. $20 \%$ casein or SPI diet group).

Table 3. Effect of low-protein diet on peritoneal cell number.

\begin{tabular}{ccc}
\hline Groups & Number of mice & Peritoneal cells $\left(\times 10^{4} / \mathrm{g}\right.$ weight $)$ \\
\hline $5 \%$ casein & 11 & $2.7 \pm 0.6^{* *}$ \\
$20 \%$ casein & 11 & $4.5 \pm 0.7$ \\
$5 \%$ SPI & 13 & $1.8 \pm 0.8^{* *}$ \\
$20 \%$ SPI & 12 & $3.4 \pm 1.1$ \\
\hline
\end{tabular}

Values are mean \pm SE. ${ }^{* *} p<0.01$ by ANOVA and Scheffé's test $(5 \%$ vs. $20 \%$ casein or SPI diet group).

casein diet group $(p<0.01)$. When total numbers of peritoneal cells were compared among the four groups (Table 3), the cell numbers of the 5\% protein diet groups were significantly decreased compared with respective 20\% diet groups $(p<0.01)$.

\section{Effect of low-protein diets on $\mathrm{O}_{2}{ }^{-}$released by macrophages}

When peritoneal macrophages are isolated in an LPS-free system from mice fed standard laboratory chow and stimulated by PMA or opsonized zymosan, the amounts of $\mathrm{O}_{2}{ }^{-}$release are reported to be less than $100 \mathrm{nmol} / \mathrm{mg}$ protein/h $(11)$. The LPS-free system makes it possible to study the activation of macrophages in vitro. After treatment with activating agents including interferon- $\gamma$, LPS, granulocyte-macrophage-colony stimulating factor, and M-CSF, macrophages dramatically increase their activity of the respiratory burst (12-16).

We first measured $\mathrm{O}_{2}{ }^{-}$secreted by resident macrophages from the four diet groups by activating protein kinase $\mathrm{C}$ with PMA, or by stimulating phagocytosis with opsonized zymosan. Then, the change in $\mathrm{O}_{2}^{-}$production was examined after incubation of macrophages for $12 \mathrm{~h}$ with LPS (Fig. 2) or M-CSF (Fig. 3). The resident macrophages isolated from $20 \%$ casein diet group released $52 \pm 5$ (mean \pm $\mathrm{SD}, n=6) \mathrm{nmol} \mathrm{O}_{2}{ }^{-} / \mathrm{mg}$ protein $/ \mathrm{h}$ with PMA and $94 \pm 9 \mathrm{nmol} \mathrm{O}_{2}{ }^{-} / \mathrm{mg}$ protein $/ \mathrm{h}$ $(n=6)$ with opsonized zymosan, respectively (Fig. 2). After incubation with LPS for $12 \mathrm{~h}$, release of $\mathrm{O}_{2}{ }^{-}$increased 2 times with PMA and 1.5 times with opsonized zymosan (Fig. 2). When the macrophages were treated with $\mathrm{M}$-CSF for $12 \mathrm{~h}, \mathrm{O}_{2}{ }^{-}$ release stimulated by PMA or opsonized zymosan was doubled.

After stimulation by PMA or opsonized zymosan, macrophages isolated from 

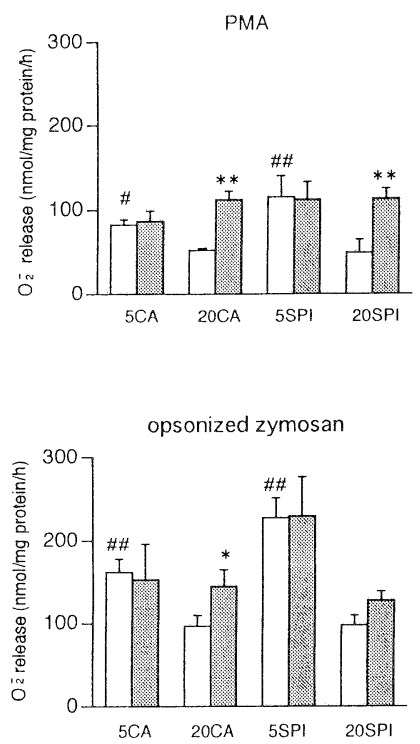

Fig. 2. Effect of low-protein diets on $\mathrm{O}_{2}{ }^{-}$release from macrophages treated with or without LPS. Resident peritoneal macrophages were individually isolated from four groups of mice and were cultivated for $12 \mathrm{~h}$ with (shaded column) or without $10 \mathrm{ng} / \mathrm{ml}$ LPS (open column). They were stimulated by $500 \mathrm{ng} / \mathrm{ml}$ PMA or $1 \mathrm{mg} / \mathrm{ml}$ opsonized zymosan. $\mathrm{O}_{2}^{-}$release was measured as described in MATERIALs AND Methods. Values are mean \pm SD for 6 mice. The abbreviations 5CA and 20CA indicate the 5\% casein and 20\% casein diet groups, and 5 SPI and 20SPI indicate the 5\% SPI and 20\% SPI diet groups, respectively. $*_{p}<0.05$ by ANOVA and Scheffé's test (resident macrophages vs. LPS-primed macrophages). ${ }^{* *} p<0.01$ by ANOVA and Scheffe's test (resident macrophages vs. LPS-primed macrophages). ${ }^{\#} p<0.05$ by ANOVA and Scheffe's test (5\% vs. $20 \%$ casein or SPI diet group in resident macrophages). ${ }^{\#} p<0.01$ by ANOVA and Scheffé's test (5\% vs. $20 \%$ casein or SPI diet group in resident macrophages).

the 20\% SPI diet group released amounts of $\mathrm{O}_{2}^{-}$similar to those observed in the 20\% casein diet group. They also responded to LPS (Fig. 2) and M-CSF (Fig. 3) and increased their capacity for PMA-stimulated $\mathrm{O}_{2}^{-}$production as shown in macrophages from $20 \%$ casein diet group. Opsonized zymosan-stimulated $\mathrm{O}_{2}{ }^{-}$ release of the cells was increased by treatment with M-CSF (Fig. 3) but not by LPS (Fig. 2). Thus, macrophages from both the 20\% casein and 20\% SPI diet groups showed almost normal respiratory burst characteristics.

In contrast, the resident macrophages from 5\% SPI diet group released significantly larger amounts of $\mathrm{O}_{2}^{-}$in response to both PMA and opsonized zymosan than those from 20\% SPI diet group $(p<0.01)$. Compared with macrophages from the 20\% casein diet group, macrophages from $5 \%$ casein diet group 

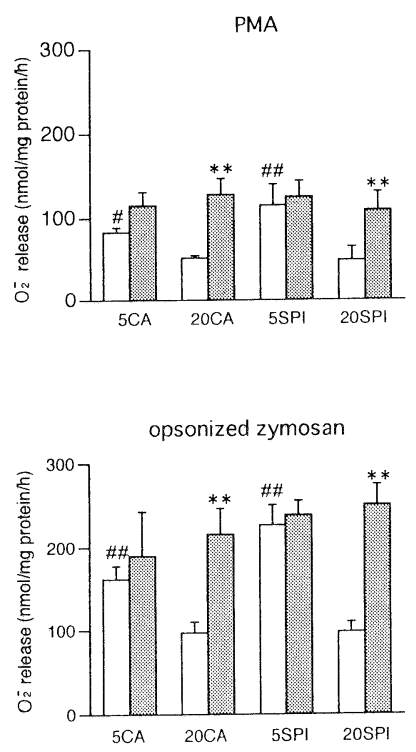

Fig. 3. Effect of low-protein diets on $\mathrm{O}_{2}{ }^{-}$release from macrophages treated with or without M-CSF. Isolated peritoneal macrophages were cultivated for $12 \mathrm{~h}$ with (shaded column) or without $1 \mu \mathrm{g} / \mathrm{ml} \mathrm{M}$-CSF (open column), then they were stimulated with $500 \mathrm{ng} / \mathrm{ml}$ PMA or $1 \mathrm{mg} / \mathrm{ml}$ opsonized zymosan. $\mathrm{O}_{2}{ }^{-}$release was measured as described in MATERIALs AND Methods. Values are mean $\pm \mathrm{SD}$ for 6 mice. $* * p<0.01$ by ANOVA and Scheffe's test (resident macrophages vs. M-CSF-primed macrophages). ${ }^{\#} p<0.05$ by ANOVA and Scheffé's test ( $5 \%$ vs. $20 \%$ casein or SPI diet group in resident macrophages). ${ }^{\#}<0.01$ by ANOVA and Scheffé's test $(5 \%$ vs. $20 \%$ casein or SPI diet group in resident macrophages).

released significantly larger amounts of $\mathrm{O}_{2}{ }^{-}$with PMA $(p<0.05)$ and with opsonized zymosan $(p<0.01)$. Macrophages from 5\% SPI diet group tended to release larger amounts of $\mathrm{O}_{2}^{-}$than those from $5 \%$ casein diet group, but the differences were not significant. To characterize the increased $\mathrm{O}_{2}{ }^{-}$production by macrophages from PM mice, they were treated with LPS (Fig. 2) or M-CSF (Fig. 3) for $12 \mathrm{~h}$, and the release of $\mathrm{O}_{2}^{-}$was measured. The capacity for $\mathrm{O}_{2}^{-}$release was not significantly increased after activation in vitro with these agents (Fig. 2 and 3).

\section{Candida phagocytosis}

Nonspecific phagocytic activity of macrophages from four groups of mice was examined after incubation with unopsonized Candida albicans (Fig. 4). Although a significant increase in $\mathrm{O}_{2}^{-}$production was observed in resident macrophages from the $5 \%$ casein and 5\% SPI diet groups, the phagocytic ability of the unopsonized particle was not changed by the diets. Opsonization of Candida particles with 


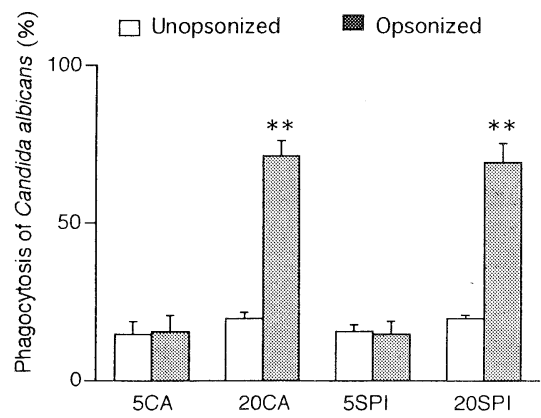

Fig. 4. Effect of low-protein diets on phagocytosis of Candida albicans by macrophages. Phagocytosis of Candida albicans by macrophages was measured as described in MATERIALS AND Methods. Values are mean \pm SD for 6 mice. ${ }^{* *} p<0.01$ by ANOVA and Scheffé's test (unopsonized Candida vs. opsonized Candida).

normal serum greatly accelerate phagocytosis through $\mathrm{Fc}$ or $\mathrm{C} 3 \mathrm{~b}$ receptor-mediated pathways (17-19). This acceleration was clearly observed in macrophages isolated from mice fed the 20\% casein and 20\% SPI diets (Fig. 4). However, this was not in the case of macrophages from the low-protein diet groups. Opsonized zymosan effectively stimulated the phagocytosis-associated respiratory burst (Figs. 2 and 3), while opsonization of Candida particle did not enhance phagocytosis at all (Fig. 4).

\section{DISCUSSION}

Partially reduced oxygen intermediates released by phagocytes play an essential role in killing invading microorganisms (3). At the same time, the intermediates have been cited as central molecules which cause tissue injury in various pathological processes including inflammation, ischemia-reperfusion injury, aging, and carcinogenesis (20-22). The $\mathrm{O}_{2}^{-}$-generating NADPH oxidase is dormant in resting phagocytes and becomes activated by a variety of stimuli. The system is strictly regulated to prevent the toxic intermediates from injuring host tissue and to function effectively only against microbes.

In our LPS-free culture system, the amount of PMA-stimulated $\mathrm{O}_{2}^{-}$release by resident peritoneal macrophages isolated from normal mice was about $50 \mathrm{nmol} / \mathrm{mg}$ protein $/ \mathrm{h}$. They were primed with LPS or M-CSF and increased the capacity for $\mathrm{O}_{2}{ }^{-}$production 2- to 3-fold (11). The amounts of PMA- or opsonized zymosanstimulated $\mathrm{O}_{2}{ }^{-}$secreted by macrophages from mice fed 20\% casein or 20\% SPI diet were within the normal range. These macrophages responded to both LPS and M-CSF and the capacity for $\mathrm{O}_{2}^{-}$production doubled. In contrast, the amounts of $\mathrm{O}_{2}{ }^{-}$released from PMA- or opsonized zymosan-stimulated macrophages of the low-protein diet groups were already enhanced, and the values were similar to those shown in the macrophages primed with LPS or M-CSF from the $20 \%$ protein diet groups. The capacity for $\mathrm{O}_{2}{ }^{-}$production was not enhanced after treatment in vitro with LPS or M-CSF. Thus, macrophages seemed to be already activated in protein-deficient mice. Although we carefully monitored the signs of infection, protein-deficient mice might have suffered from latent infection or be exposed to microbial cell components like LPS due to the decreased mucosal barrier (23). The 
increased production of macrophage-derived oxygen intermediates may be involved in the enhanced lipid peroxidation in protein-deficient rats (24).

Macrophage activation is accomplished during infection through the release of macrophage-activating cytokines from immune cells specifically sensitized to antigens from the infecting organism. Activated macrophages increase IgG Fc receptors, chemotaxis, phagocytosis, phagocytosis-associated respiratory burst, and secretion of lysozomal enzymes, all of which are important for enhanced capacity for killing microorganisms or tumor cells. Although macrophages from PM mice exhibited an enhanced capacity for $\mathrm{O}_{2}{ }^{-}$production, they showed different functional characteristics from normal activated macrophages. The numbers of peritoneal cell counts were apparently decreased in PM mice (Table 3).

Nonspecific phagocytosis of unopsonized Candida by macrophages was not affected under PM. This process has been suggested to be mediated through mannose receptors (25), suggesting that the mannose receptor-mediated pathway may be resistant to PM. In contrast, there was no acceleration of phagocytosis by opsonization of Candida particles when mice were fed $5 \%$ casein or $5 \%$ SPI. The present experiments did not show the mechanism by which macrophages under PM were defective in opsonization. The resident macrophages from PM mice could respond to opsonized zymosan and released larger amounts of $\mathrm{O}_{2}{ }^{-}$than those from mice fed $20 \%$ protein diets, suggesting that the stimulation of $\mathrm{Fc}$ and $\mathrm{C} 3 \mathrm{~b}$ receptors may be intact. Keusch et al. reported that cell surface receptors for IgG on macrophages were preserved in protein deficient-weaning rats (26).

Although a precise correlation between the in vitro assessment of phagocyte function and susceptibility to microbial infection has not been firmly established, many lines of current evidence suggest that the increased incidence of infection in malnourished children may be, at least in part, due to defective phagocyte function $(27,28)$. Studies of PM to date including this study have revealed that PM impairs chemotaxis and phagocytosis and produces abnormal metabolic functions of macrophages. The abnormal metabolic functions include the increased resting activity of the hexose monophosphate shunt with impaired activation during phagocytosis (29) and decreased iodination during particle ingestion (1). However, specific enzyme dysfunction leading to the impaired metabolic activities has not been identified.

In the present study, functional alterations of macrophages were confirmed using food proteins of different quality. SPI is slightly inferior to casein as a protein source, as shown in the growth curve of Fig. 1. The numbers of peritoneal cells decreased in PM mice. The average numbers of the cells from $\mathrm{C} 3 \mathrm{H} / \mathrm{He}$-slc mice fed a standard laboratory chow are between 3.5 and $5.0 \times 10^{4} \mathrm{cells} / \mathrm{g}$ body weight. The numbers of $20 \%$ casein and 20\% SPI diet groups were within the normal range. Compared with the 5\% casein diet, the 5\% SPI diet tended to decrease peritoneal cell numbers and increase $\mathrm{O}_{2}^{-}$production by resident macrophages. Feeding of these low-protein diets for a longer period may produce significant differences. The $5 \%$ SPI diet-induced alterations of the macrophage functions were completely 
prevented when mice were fed the $20 \%$ SPI diet. These results suggest that the quality and quantity of dietary protein may be important modulators for macrophage functions.

Phagocytosis of the invading organisms in the presence of opsonins is the initial step to process antigen and present it in a biochemically modified form to lymphocytes during the development of specific immunity. Macrophage dysfunctions shown in this study may play a part in the impaired immune response under PM. At the same time, the enhanced production of $\mathrm{O}_{2}{ }^{-}$by resident macrophages may be deleterious to the host, causing tissue injury under PM.

\section{REFERENCES}

1) Gross, R. L., and Newberne, P. M. (1980): Role of nutrition in immunologic functions. Physiol. Rev., 60, 188-302.

2) Nathan, C. F. (1987): Secretory products of macrophages. J. Clin. Invest., 79, 319326.

3) Johnston, R. B., Jr., Keele, B. B., Jr., Misra, H. P., Lehmeyer, J. E., Webb, L. S., Baehner, R. L., and Rajagopalan, K. V. (1975): The role of superoxide anion generation in phagocytic bactericidal activity: Studies with normal and chronic granulomatous disease leukocytes. J. Clin. Invest., 55, 1357-1372.

4) Segal, A. W. (1989): The electron transport chain of the microbicidal oxidase of phagocytic cells and its involvement in the molecular pathology of chronic granulomatous disease. J. Clin. Invest., 83, 1785-1793.

5) Holmes, B., Page, A. R., and Good, R. A. (1967): Studies of the metabolic activity of leukocytes from patients with a genetic abnormality of phagocytic function. J. Clin. Invest., 46, 1422-1432.

6) Yamanishi, K., Takahashi, M., Nishida, T., Ohmoto, Y., Takano, M., Nakai, S., and Hirai, Y. (1991): Renaturation, purification, and characterization of human truncated macrophage colony-stimulating factor expressed in Escherichia coli. J. Biochem. Tokyo, 109, 404-409.

7) Rokutan, K., Thomas, J. A., and Johnston, R. B., Jr. (1991): Phagocytosis and stimulation of the respiratory burst by phorbol diester initiate S-thiolation of specific proteins in macrophages. J. Immunol., 147, 260-264.

8) Johnston, R. B., Jr. (1984): Measurement of $\mathrm{O}_{2}{ }^{-}$secreted by monocytes and macrophages. Method. Enzymol., 105, 365-369.

9) Lowry, O. H., Rosebrough, N. J., Farr, A. L., and Randall, R. J. (1951): Protein measurement with the Folin phenol reagent. J. Biol. Chem., 193, 265-275.

10) Maródi, M., Korchak, H. M., and Johnston, R. B., Jr. (1991): Mechanisms of host defense against Candida species. J. Immunol., 146, 2783-2789.

11) Pabst, M. J., and Johnston, R. B., Jr. (1980): Increased production of superoxide anion by macrophages exposed in vitro to muramyl dipeptide or lipopolysaccharide. $J$. Exp. Med., 151, 101-114.

12) Cassatella, M. A., Bianca, V. D., Berton, G., and Rossi, F. (1985): Activation by gamma interferon of human macrophage capability to produce toxic oxygen molecules is accompanied by decreased $K_{\mathrm{m}}$ of the superoxide-generating NADPH oxidase. 
Biochem. Biophys. Res. Commun., 132, 908-914.

13) Nathan, C. F., Prendegast, T. J., Wiebe, M. E., Stanley, E. R., Platzer, E., Remold, H., Welte, K., Rubin, B. Y., and Murray, H. W. (1984): Activation of human macrophages. J. Exp. Med., 160, 600-605.

14) Wing, E. J., Ampel, N. M., Waheed, A., and Shadduck, R. K. (1985): Macrophage colony-stimulating factor (M-CSF) enhances the capacity of murine macrophages to secrete oxygen reduction products. J. Immunol., 135, 2052-2056.

15) Ampel, N. M., Wing, E. J., Waheed, A., and Shadduck, R. K. (1986): Stimulatory effect of purified macrophage colony-stimulating factor on murine resident peritoneal macrophages. Cell. Immunol., 97, 344-356.

16) Sasada, M., Pabst, M. J., and Johnston, R. B., Jr. (1983): Activation of mouse peritoneal macrophages by lipopolysaccharide alters the kinetic parameters of the superoxide-producing NADPH oxidase. J. Biol. Chem., 258, 9631-9635.

17) Mellman, I., Koch, T., Healey, G., Hunziker, W., Lewis, V., Plutner, H., Miettinen, H., Vaux, D., Moore, K., and Stuart, S. (1988): Structure and function of Fc receptors on macrophages and lymphocytes. J. Cell. Sci. (Suppl.), 9, 45-65.

18) Law, S. K. A. (1988): C3 receptors on macrophages. J. Cell. Sci. (Suppl.), 9, 67-97.

19) Huber, H., Douglas, S. D., and Fundenberg, H. H. (1969): The IgG receptor: An immunological marker for the characterization of mononuclear cells. Immunology, 17, $7-21$.

20) Weisiger, R. A. (1986): Oxygen radicals and ischemic tissue injury. Gastroenterology, 90, 494-496.

21) Ames, B. N., Shigenaga, M. K., and Hagen, T. M. (1993): Oxidants, antioxidants, and the degenerative diseases of aging. Proc. Natl. Acad. Sci. U.S.A., 90, 7915-7922.

22) Ames, B. N. (1983): Dietary carcinogens and anticarcinogens. Science, 221, 12561264.

23) Chandra, R. K., and Wadhwa, M. (1993): Nutritional Deficiencies and Intestinal Mucosal Immunity, ed. by Walker, W. A., Harmatz, P. R., and Wershil, B. K., Academic Press. Inc., New York, pp. 389-399.

24) Rumley, E. J. S., Lai, A., Hirakawa, T., Kido, Y., Shizuka, F., and Kishi, K. (1992): Protein deficiency potentiates lipid peroxidation in growing rats exposed to hyperoxia. Nutr. Res., 12, 1101-1112.

25) Ezekowitz, R. A. B., and Stahl, P. D. (1988): The structure and function of vertebrate mannose lectin-like protein. J. Cell. Sci. (Suppl.), 9, 121-133.

26) Keusch, G. T., Douglas, S. D., Braden, K., and Geller, S. A. (1978): Antibacterial functions of macrophages in experimental protein-calorie malnutrition. I. Description of the model, morphologic observations, and macrophage surface $\mathrm{IgG}$ receptors. J. Infect. Dis., 138, 125-133.

27) Schopfer, K. S., and Schopfer, D. (1976): Neutrophil function in children with kwashiorkor. J. Lab. Clin. Med., 88, 450-461.

28) Yoshida, T., Metcoff, J., Frenk, S., and Peng, C. D. (1967): Intermediary metabolites and adenine nucleotides in leukocytes of children with PCM. Nature, 214, 525-526.

29) Keusch, G. T., Douglas, S. D., Hammer, G., and Ugurbil, K. (1977): Macrophage function in experimental protein-calorie malnutrition, in Malnutrition and the Immune Response, ed. by Suskind, R. M., Raven Press, New York, pp. 277-283. 